\title{
The 'Last Hurrah of the Reigning Darwinulocopines'? Ostracoda (Arthropoda, Crustacea) from the Lower Jurassic Moenave Formation, Arizona and Utah, USA
}

\author{
Lucas S. Antonietto, ${ }^{1}$ Lisa E. Park Boush, ${ }^{1}$ Celina A. Suarez, ${ }^{2}$ Andrew R.C. Milner, ${ }^{3}$ and \\ James I. Kirkland ${ }^{4}$ \\ ${ }^{1}$ Center for Integrative Geosciences, University of Connecticut, Charles Lewis Beach Hall, 354 Mansfield Road, U-1045, Storrs, Mansfield, \\ Connecticut 06269, USA 〈lucas.antonietto@uconn.edu〉〈lisa.park_boush@uconn.edu〉 \\ ${ }^{2}$ Department of Geosciences, University of Arkansas, G. David Gearhart Hall, 340 North Campus Drive, Fayetteville, Arizona 72701, USA \\ 〈casuarez@uark.edu〉 \\ ${ }^{3}$ St. George Dinosaur Discovery Site at Johnson Farm, 2180 East Riverside Drive, St. George, Utah 84790, USA 〈arcmilner@gmail.com〉 \\ ${ }^{4}$ Utah Geological Survey, 1594 West North Temple, P.O. Box 146100, Salt Lake City, Utah 84114, USA 〈jameskirkland@utah.gov〉
}

\begin{abstract}
An ostracode fauna is described from lacustrine sediments of the Hettangian, Lower Jurassic, Whitmore Point Member of the Moenave Formation. The Moenave is well known for its rich, Late Triassic?-Early Jurassic fossil record, which includes fossil fishes, stromatolites, ostracodes, spinicaudatans, and a diverse ichnofauna of invertebrates and vertebrates. Four ostracode species, all belonging to the suborder Darwinulocopina, were recovered from these sediments: Suchonellina globosa, S. stricta, Whipplella? sp. 1, and W.? sp. 2. The diversity and composition of the Whitmore Point Member ostracode fauna agree with previous interpretations about Lake Dixie and nearby paleoenvironments as shallow lakes inhabited by darwinulocopine species that survived the effects of the Central Atlantic Magmatic Province and the subsequent end-Triassic extinction and quickly recolonized these areas, thanks to asexual reproduction by parthenogenesis. The Lake Dixie region, in its geographical isolation, could represent the last episode of darwinulocopine dominance in nonmarine environments before the Late Jurassic diversification of the cypridocopine/cytherocopine modern ostracodes.
\end{abstract}

\section{Introduction}

The present work identifies and redescribes some of the species of an ostracode fauna that was recovered from sediments of the Hettangian, Lower Jurassic, Whitmore Point Member, Moenave Formation, Glen Canyon Group. We extend the scientific knowledge of ostracode diversity from this formation by addressing their taxonomy, along with major diversification trends of the ostracode suborder Darwinulocopina Sohn, 1988 (darwinulocopines) during the early Mesozoic. The Moenave Formation (Fig. 1) extends from southwestern Utah State into northwestern Arizona State, USA, and consists of sediments deposited under fluvial-lacustrine environments (Tanner and Lucas, 2007). Its fossil record is well documented, comprising numerous and diverse fossil fishes (nonmarine sharks, semionotids, 'palaeoniscoids,' coelacanths, and lungfishes), stromatolites, ostracodes, spinicaudatans, and a diverse ichnofauna of invertebrates and vertebrates (Milner and Kirkland, 2006; Milner et al., 2012; Kirkland et al., 2002, 2014), which were most recently summarized by Harris and Milner (2015).

According to Schudack (2006), the ostracode fauna of the Moenave Formation comprises a restricted number of poorly known species of darwinulocopines (genus Darwinula Brady and Robertson in Jones, 1885) and an indeterminate genus of cypridocopines (suborder Cypridocopina Jones in Chapman, 1901). In contrast, the Late Jurassic Morrison Formation, which is widespread through the midwestern USA, presents a diverse fauna of early nonmarine cytherocopines (suborder Cytherocopina Gründel, 1967, e.g., Timiriasevia Mandelstam, 1947, and Theriosynoecum Branson, 1936). The Morrison is the earliest unit in which cytherocopines and cypridocopines became dominant in US nonmarine faunas, while still associated with the remaining darwinulocopines (Schudack et al., 1998). The faunal composition of the Moenave and Morrison formations is in accordance with major evolutionary trends of these three taxa during the late Paleozoic-early Mesozoic (Whatley, 1988; Sames and Horne, 2012).

The Triassic-Jurassic transition is marked by the end-Triassic extinction event (ETE), one of the five major extinctions in Earth history (Beerling and Berner, 2002). There are several interpretations of the lithologic position of the ETE in the Glen Canyon Group, ranging from the contact between the Moenave and Kayenta formations (Milner et al., 2012; Kirkland et al., 2014) to the transition from the Dinosaur Canyon Member to the Whitmore Point Member of the Moenave Formation (Lucas et al., 2011). However, recent chemostratigraphic and detrital zircon studies suggest that the ETE occurred in the lower Dinosaur Canyon Member (Suarez et al., 2017). Considering the evolutionary trend 


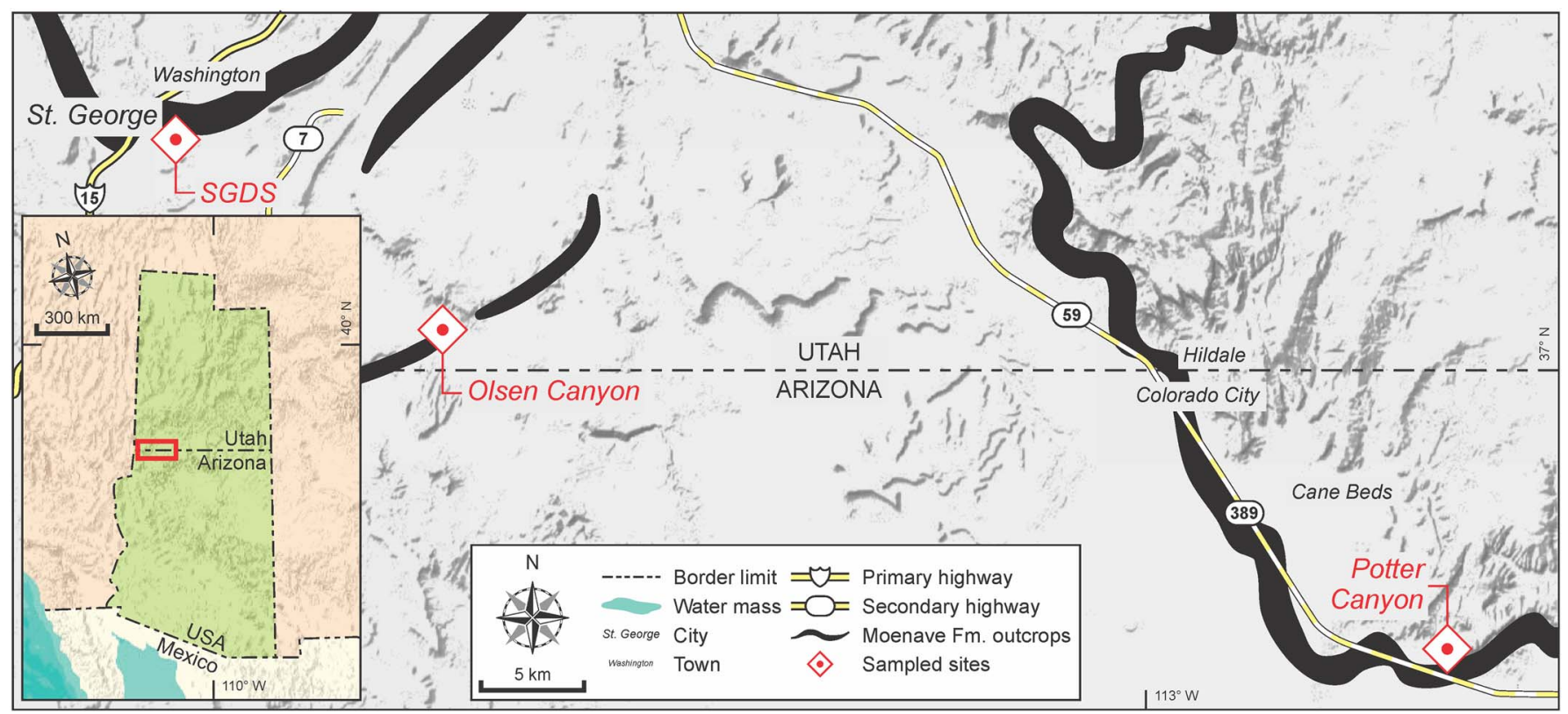

Figure 1. Location of Moenave Formation outcrops and sampling points studied in the present work, Utah and Arizona, USA. Map semiology follows the Federal Geographic Data Committee (2006).

toward drastically diminished diversity of the darwinulocopines at the end of the Triassic, the sediments of the Moenave Formation are very important to the understanding of nonmarine ostracode evolution at a time when the cypridocopines and cytherocopines were supposedly starting to compete for ecological niches with the more ancient darwinulocopines (Sohn, 1988; Whatley, 1988; Horne, 2003).

\section{Geological setting}

The Moenave Formation is the lowermost unit of the Glen Canyon Group in southwestern Utah and northwestern Arizona (Lucas et al., 2011). It was deposited in a retro-arc basin known as the Zuni Sag (Blakey, 1994; Kirkland and Milner, 2006; Milner et al., 2012; Kirkland et al., 2014), formed on the western edge of the North American craton as a result of its collision with the Cordilleran magmatic arc system that would give rise to the Nevadan orogeny (Renne and Turrin, 1987; Tanner and Lucas, 2009). The basal contact of the Moenave with the underlying Chinle Formation is an abrupt erosive contact in which the conglomerate at the top of the latter is locally eroded (Martz et al., 2017). The overlying Springdale Sandstone Member of the Kayenta Formation also erodes into the top of the Moenave (Lucas and Tanner, 2006).

Stratigraphic information.-The Moenave Formation is composed of sediments deposited in a mosaic of fluvial, lacustrine, and eolian subenvironments. The Wingate Sandstone Member of the Kayenta Formation-an eolian, sandstone erg sequence-interfingers with the Moenave in the northeastern part of its outcrop belt (Blakey, 1994; Tanner and Lucas, 2007; Blakey and Rainey, 2008). Stratigraphic nomenclature currently in use subdivides the Moenave Formation into the Dinosaur Canyon and Whitmore Point members (Fig. 2), in ascending order (Biek et al., 2009, 2010). The Dinosaur Canyon Member is a succession of fluvial sandstones and mudstones that become increasingly eolian eastward and represent a northwest-trending alluvial system (Kirkland and Milner, 2006; Lucas and Tanner, 2007). The Whitmore Point Member sediments were deposited in and along the margins of an extensive lake system-Lake Dixie (Fig. 3) - during a wet climatic interval when an inland delta on the northern end of the Zuni Sag became flooded (Milner et al., 2012).

The upper contact of the Dinosaur Canyon Member with the Whitmore Point Member in southwestern Utah is often placed at the base of a pale green-gray, sometimes stromatolitic limestone unit that is partially replaced by red chert (Wilson, 1967; Kirkland and Milner, 2006; Milner et al., 2012; Kirkland et al., 2014). Associated with this transition, tracks of the crocodylomorph Batrachopus Hitchcock, 1845 and the dinosaurians Eubrontes Hitchcock, 1845 and Anomoepus Hitchcock, 1848 are thought to be a biostratigraphic indicator of the Triassic-Jurassic boundary in the lower-middle part of the Dinosaur Canyon (Olsen et al., 2002; Lucas and Tanner, 2007). In the Olsen Canyon area, these track types first appear near the middle of the Dinosaur Canyon (Milner et al., 2012; Kirkland et al., 2014). Recent carbon isotope chemostratigraphy, detrital zircon geochronology, and a reassessment of the magnetostratigraphy of Donohoo-Hurley et al. (2010) suggests that the ETE is associated with these levels, whereas the Triassic-Jurassic boundary occurs in the upper Dinosaur Canyon to lower Whitmore Point members (Suarez et al., 2017).

Locality information.-Sections of the Moenave Formation studied in the present work include those at St. George Discovery Site at Johnson Farm (SGDS) $\left(37^{\circ} 06^{\prime} 05^{\prime \prime N}\right.$, $\left.113^{\circ} 32^{\prime} 08^{\prime \prime} \mathrm{W}\right)$ and Olsen Canyon $\left(37^{\circ} 01^{\prime} 02^{\prime \prime} \mathrm{N}, 113^{\circ} 23^{\prime} 22^{\prime \prime} \mathrm{W}\right)$, near the city of St. George, Washington County, Utah, and Potter Canyon $\left(36^{\circ} 52^{\prime} 44.4^{\prime \prime} \mathrm{N}, 112^{\circ} 50^{\prime} 31.2^{\prime \prime} \mathrm{W}\right)$, Mohave County, Arizona. A full description of the SGDS and Potter 


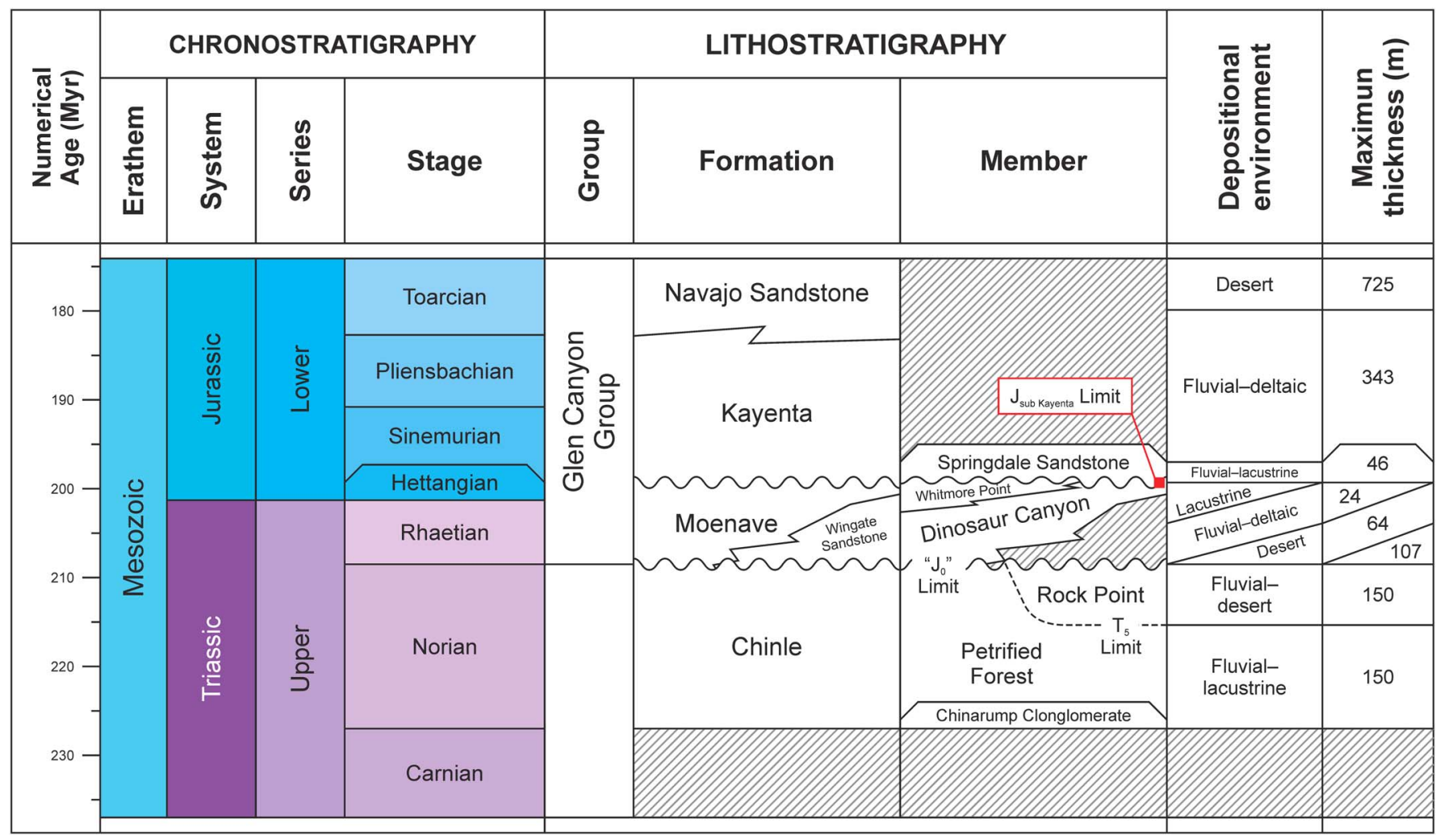

Figure 2. Lithological chart of the Glen Canyon Group in Utah and Arizona, USA, after Lucas et al. (1997), Mathis (2000), and Tanner and Lucas (2007).

Canyon sites was provided by Kirkland et al. (2014). A description of the Olsen Canyon section is provided in Supplemental Data 1 of the present work.

\section{Materials and methods}

Samples collected at field sites (Fig. 4) were prepared at the Center for Integrative Geosciences of UConn, following the methodology of Antonietto et al. $(2015,2016)$. These samples were disaggregated with $50 \mathrm{~mL}$ of $30 \%$ hydrogen peroxide $\left(\mathrm{H}_{2} \mathrm{O}_{2}\right)$ in a $1 \mathrm{~L}$ tall glass beaker for $\sim 48 \mathrm{~h}$. After disaggregation, $25-50 \mathrm{~mL}$ of absolute ethanol was added to each sample $/ \mathrm{H}_{2} \mathrm{O}_{2}$ solution to interrupt the reaction. The resulting mixtures were individually washed with tap water into $250 \mathrm{~mL}$ beakers and dried in a Thermo Fisher Isotemp ${ }^{\circledR}$ 630F furnace at $70^{\circ} \mathrm{C}$. Sediments were then separated using a set of 600,200 , 150 and $75 \mu \mathrm{m}$ Tyler ${ }^{\mathrm{TM}}$ sieves and the ostracodes were removed under an Olympus S230 stereoscopic microscope.

Carapaces and valves of the identified species were photographed at the Old World Archaeobotany Laboratory of the University of Connecticut (UConn) Anthropology Department, Mansfield, USA. The scanning electron microscope (SEM) used was a JCM-6000PLUS NeoScope Benchtop, at low-vacuum mode and $10 \mathrm{kV}$ filament voltage, with no contrast-enhancing coating. Additional images of rock samples preserving ostracode extinction levels were taken with a Macropod Pro 3D device coupled with Zerene Stacker 'focus stacking' software. Specimens were measured with Adobe Acrobat Pro software, by converting photographs into portable document format (PDF) files and then using the software measuring tool. Abbreviations used in the text include: $\mathrm{H}=$ height; $\mathrm{L}=$ length, $\mathrm{W}=$ width.

Repositories and institutional abbreviations.-The materials photographed for this study (13 specimens of four species from two families) are housed in the collections of the Natural History Museum of Utah (NHMU) in Salt Lake City, USA, under the prefix UMNH (Utah Natural History Museum, former name of the NHMU), combined with the second prefix IP (invertebrate paleospecimens and localities) and numbers 5292-5304. Samples collected at the SGDS are housed at the SGDS museum (Washington County, Utah), whereas those from Olsen and Potter canyons are currently at the Center for Integrative Geosciences, UConn. Other repositories include The Natural History Museum, London (BMNH).

\section{Systematic paleontology}

The classification above family level used herein follows Liebau (2005). The taxonomy of lower ranks is based on Molostovskaya (2000), although with reservations that will be further discussed in this paper. Morphological terminology is that used by Moore (1961). Four species recovered from the present samples are listed below. Two were left in open nomenclature, Whipplella? sp. 1 and W.? sp. 2, whereas the other two were identified as Suchonellina globosa (Jones, 1862) and S. stricta (Jones, 1894). These species were previously assigned to the genus Darwinula, but are herein transferred to Suchonellina Spizharsky, 1937. The type species of Suchonellina, S. inornata Molostovskaya, 1980, is properly established. 


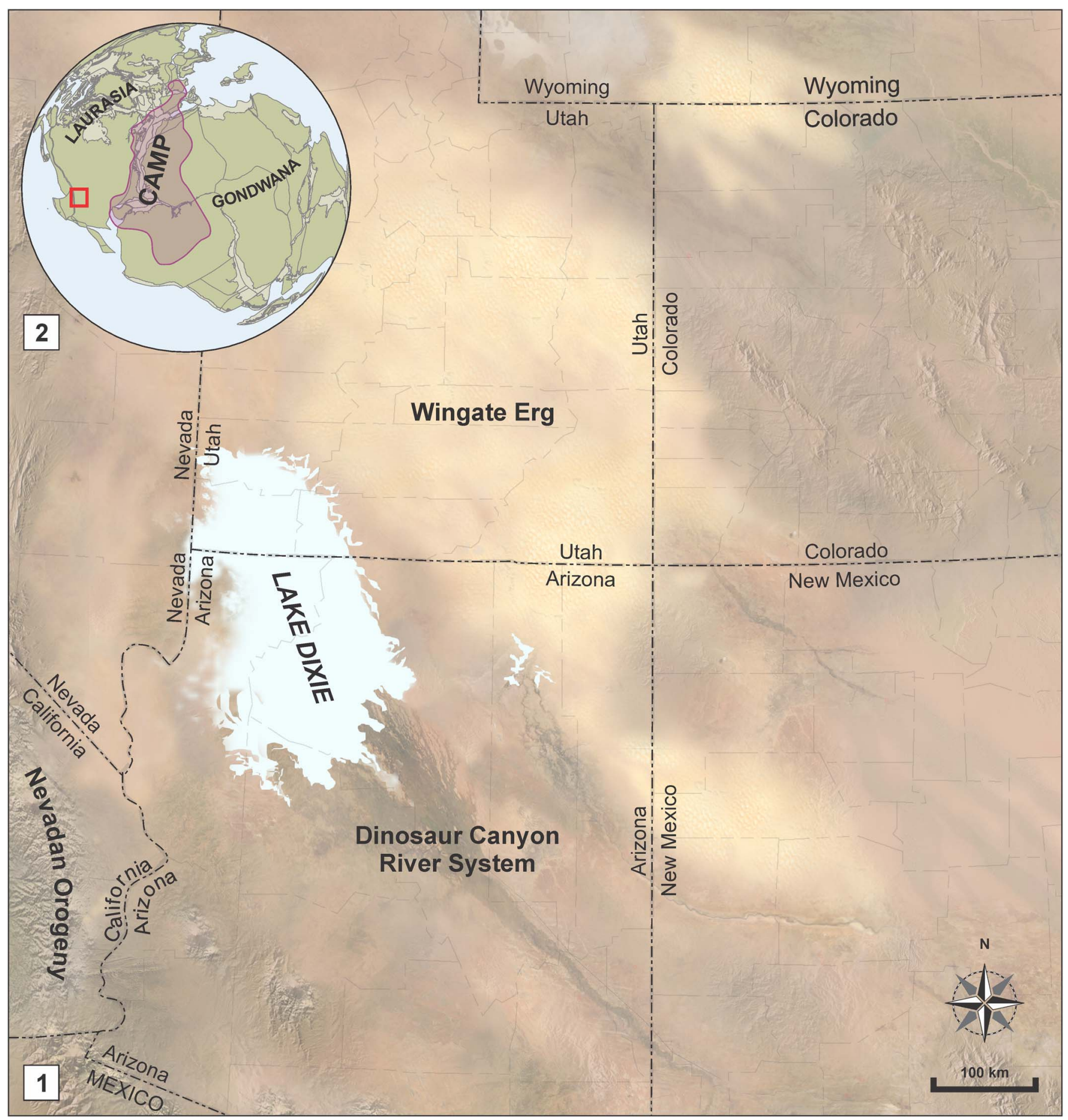

Figure 3. (1) Paleogeographic map of the southwestern USA during Whitmore Point Member time (Blakey and Ranney, 2008; Kirkland et al., 2014), and (2) its position in comparison to Laurasia, Gondwana, and the Central Atlantic Magmatic Province (CAMP) (Suarez et al., 2017). Map semiology follows the Federal Geographic Data Committee (2006).

Current status of the taxonomy of fossil and living darwinulocopines.—Previous studies on Paleozoic ostracodes (Spizharsky, 1937; Mandelstam, 1956; Belousova, 1961; Molostovskaya, 1979, 1980, 1982, 1990, 1996; Kashevarova and Neustrueva, 1982; Kukhtinov, 1985) described several families and genera to accommodate the diversity of darwinulocopines in strata from eastern European Russia. These classification systems relied heavily on features such as the number and format of the individual scars on the central muscle scar field. Other characters utilized were mostly related to the general layout of the carapace, such as the shapes of the dorsal and ventral margins, overlap of the valves along their free margin, the magnitude of the cardinal angles and overall shape of the carapace in dorsal view.

While reviewing Recent and Mesozoic darwinulocopines from Scotland, Wakefield (1996) demonstrated how highly variable central muscle scars could be, even within 
SGDS

\author{
톤
}

要要

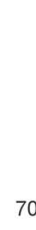

70

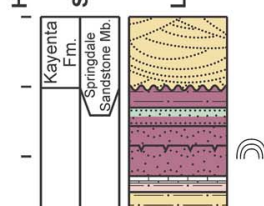

闪 (1) $\rightarrow$ एक

: $\dot{0}_{0}^{\circ}$

$0_{0}^{\circ}$

(0)

$\rightarrow$

65
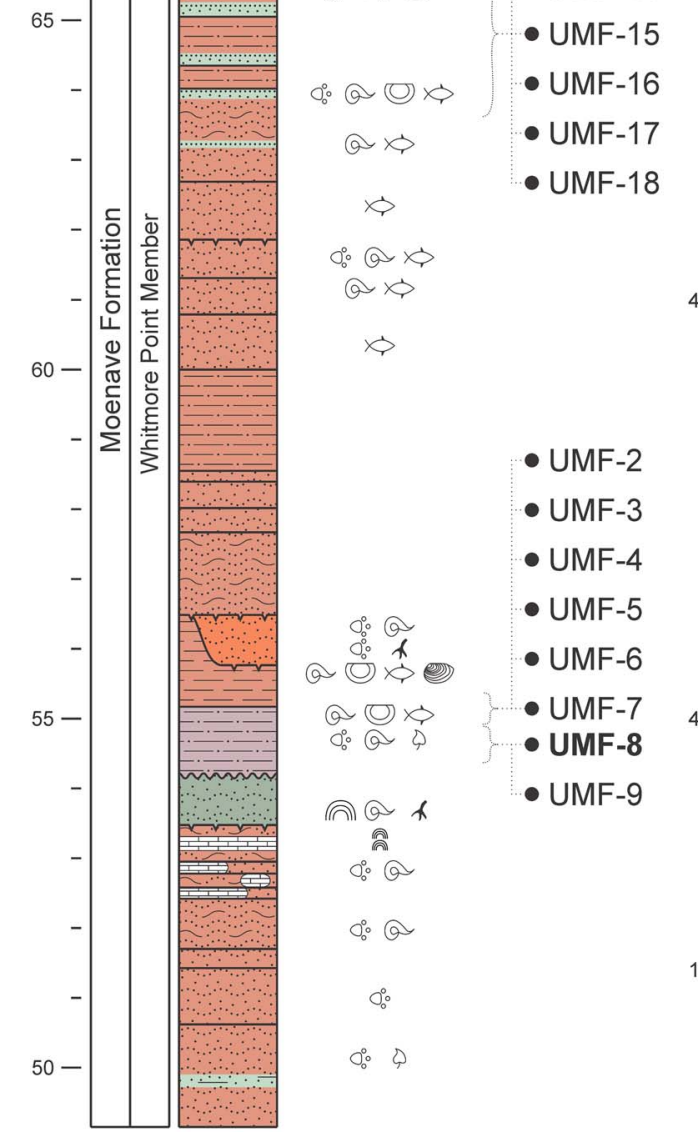

ब $₫$

ก $@$ א

กิ

$\therefore$ @

$\therefore$

$0_{0}^{\circ}$

$\because 8$

\section{OLSEN CANYON}

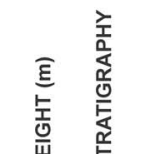

- UMF-10

- UMF-12

- UMF-13

- UMF-14

- UMF-15

- UMF-16

- UMF-18

항

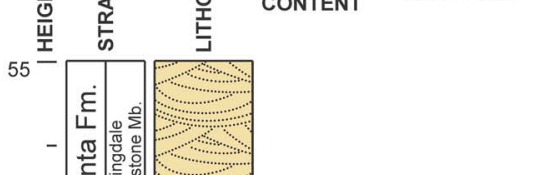

- UMF-2

- UMF-3

- UMF-4

- UMF-5

- UMF-6

- UMF-7

- UMF-8

- UMF-9

FOSSIL
CONTENT SAMPLING

\section{Plain-bedded sandstone \\ Cross-bedded sandstone \\ Ripple-bedded sandstone}

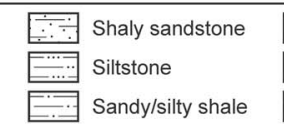

$\begin{array}{ll}\therefore & \text { Shaly sandstone } \\ \cdots & \text { Siltstone } \\ \ldots- & \text { Sandy/silty shale }\end{array}$

E- Shale

Limestone

Sandy limestone

\section{POTTER CANYON}

Figure 4. Lithology of sampled Moenave Formation outcrops in the Utah and Arizona, USA: St. George's Discovery Site at Johnson Farm (SGDS), Olsen Canyon, and Potter Canyon. Sample numbers in bold indicate those that yielded specimens in the present work. Semiology follows the Federal Geographic Data Committee (2006).

darwinulocopine species, i.e., Darwinula stevensoni (Brady and Robertson, 1870) and D. cicatricosa Wakefield, 1994. This variability, along with those of the shape of dorsal and ventral margins, layout in dorsal view and the magnitude of the cardinal angles, were also observed at the generic level by Rossetti and Martens (1998) while reviewing species of Darwinula, 
Alicenula Rossetti and Martens, 1998, Penthesilenula Rossetti and Martens, 1998, and Vestalenula Rossetti and Martens, 1998. To separate genera, these authors relied on carapace length/height/width (size) ratios and the presence, shape, and position of marginal teeth on the internal surface and keels along the free margin of the valves, but most of all on an analysis of soft parts.

Until now, no attempts have been carried out to integrate taxonomic approaches for fossil and living darwinulocopine species. Aside from carapace size ratios, the presence of morphological characters such as marginal inner teeth, keels along the free margin, and, obviously, soft parts has never been evaluated in fossil taxa. At the same time, there is no assessment of the rates of overlap of the valves along their free margins for the Recent taxa. A wide morphological analysis of key specimens from several families and superfamilies, especially those from the Paleozoic and Cenozoic, will lead to improvements on that topic. Such effort, however, is not in the scope of the present work.

Subclass Ostracoda Latreille, 1802

Superorder Podocopomorpha Kozur, 1972

Order Podocopida Sars, 1866

Suborder Darwinulocopina Sohn, 1988

Superfamily Darwinuloidea Brady and Norman, 1889

Family Darwinulidae Brady and Norman, 1889

Genus Suchonellina Spizharsky, 1937

Type species.-Suchonellina inornata Molostovskaya, 1980, by subsequent designation (herein).

Remarks.-The type species for Suchonellina was not assigned in the original description of the genus (Spikharsky, 1937), something that was tentatively corrected by Benson et al. (1961), who identified Cythere (Cytherella?) inornata McCoy in King, 1850 as Suchonellina cf. S. inornata Spikharsky, 1937. However, it was unnoticed to them that T.N. Spizharsky named this species assuming that it was similar to but not the same as Cythere (Cytherella?) inornata (hence the 'cf.', or conferre, from the Latin=compare to). Considering that Cythere (Cytherella?) inornata and S. inornata are not the same species, and that the binomial name $S$. inornata was first coined as such by Molostovskaya (1980), the present authors establish $S$. inornata as the type species of Suchonellina.

\section{Suchonellina globosa (Jones, 1862)}

Figure 5.1-5.13

1862 Candona (?) globosa Duff, 1842; Jones, p. 126, pl. 5, figs. 23, 24.

1894 Darwinula globosa; Jones, p. 163, pl. 9, figs. 3, 4a, b.

non 1894 Darwinula globosa var. stricta Jones, p. 164, pl. 9, fig. 5.

1951 Darwinula sp. (803); Wicher, p. 757, pl. 1, fig. $17 \mathrm{a}, \mathrm{b}$.

?1962 Darwinula (102); Christensen, p. 94, pl. 3, fig. 3a-g. non 1963 Darwinula globosa; Dadlez and Kopik, p. 163, pl. 1 , fig. 9.
$1963 \quad$ Notocythere media excelsa Will, 1953; Dadlez and Kopik, p. 139, pl. 1, fig. 10.

1964 'Darwinula' globosa (Jones, 1862); Anderson, p. 135 , pl. 15, fig. 128.

?1979 Darwinula spp.; Sohn and Chatterjee, p. 584, pl. 1, fig. 6, pl. 2, figs. 1-3, 5-9, 14-16.

?1983 Darwinula liulingchuanensis Zhong, 1964; Wei et al., p. 172, pl. 53, fig. 5D, R.

1983 Darwinula longovata Wei; Wei et al., p. 172, pl. 53, fig. 6D, R.

1984 Darwinula longovata; Wei, p. 350, pl. 2, figs. 14-17.

1987 Darwinula sp.; Kietzke, p. 123, fig. 2J-N.

1988 Darwinula subovatiformis Su et al., 1980; Xu, p. 1286 , pl. 2, fig. 4 .

1995 Darwinula sarytirmensis (sic) Sharapova [in Mandelstam], 1947; Kietzke and Lucas, p. 27, fig. 2I-L.

2002 Darwinula maanshanensis Hou; Hou et al., p. 753, pl. 303, figs. 1-4.

2006 Darwinula sp.; Schudack, p. 428, fig. 2A-F.

Lectotype.-BMNH I 6086, designated by Anderson (1964).

Occurrence.-Rhaetian, Upper Triassic, Inner Moray Firth Basin, Linksfield, Elgin, Morayshire County, Scotland, UK (type locality) (Jones, 1862, 1894; Anderson, 1964). Upper Triassic, Wayaobu Formation, Shaanxi Province (Xu, 1988); Lower Jurassic, Ziliujing Formation, Sichuan Province, and Xialufeng Formation, Yunnan Province, China (Wei et al., 1983; Wei, 1984; Hou et al., 2002). Lower Rhaetian, Upper Triassic, Germany (Wicher, 1951). Lower Rhaetian, 'Zbąszynecka Series,' Upper Triassic, Poland (Dadlez and Kopik, 1963). Upper Triassic, Upper Shale and Redonda members, Chinle Formation, and Sloan Canyon Formation, New Mexico, USA (Kietzke, 1987). Sinemurian to Toarcian, Lower Jurassic, Kayenta Formation, Glenn Canyon Group, Arizona, USA (Kietzke and Lucas, 1995). In the present work, extended to the Hettangian stage, Lower Jurassic, Whitmore Point Member, Moenave Formation, Arizona and Utah, USA.

Materials.-Carapaces: UMNH.IP 5303 (adult; $0.88 \mathrm{~mm} \mathrm{~L}$, $0.40 \mathrm{~mm} \mathrm{H}, 0.35 \mathrm{~mm} \mathrm{~W}$ ), UMNH.IP 5293 (adult; $0.94 \mathrm{~mm} \mathrm{~L}$, $0.47 \mathrm{~mm} \mathrm{H}, 0.39 \mathrm{~mm} \mathrm{~W}$ ), UMNH.IP 5301 (A-1 juvenile?; $0.80 \mathrm{~mm} \mathrm{~L}, 0.41 \mathrm{~mm} \mathrm{H}, 0.34 \mathrm{~mm} \mathrm{~W}), \quad$ UMNH.IP 5292 (A-2 juvenile; $0.67 \mathrm{~mm} \mathrm{L,} 0.35 \mathrm{~mm} \mathrm{H}, 0.25 \mathrm{~mm} \mathrm{~W}$ ), UMNH.IP 5302 (A-3 juvenile; $0.63 \mathrm{~mm} \mathrm{~L}, 0.31 \mathrm{~mm} \mathrm{H}, 0.20 \mathrm{~mm} \mathrm{~W}$ ), and UMNH.IP 5304 (A-4 juvenile; $0.50 \mathrm{~mm} \mathrm{L,} 0.27 \mathrm{~mm} \mathrm{H}$, $0.17 \mathrm{~mm} \mathrm{~W}$ ). Valves: UMNH.IP 5296 (adult, left; $0.95 \mathrm{~mm} \mathrm{~L}$, $0.49 \mathrm{~mm} \mathrm{H}, 0.24 \mathrm{~mm} \mathrm{~W}$ ) and UMNH.IP 5297 (adult?, right; $0.84 \mathrm{~mm} \mathrm{~L}, 0.43 \mathrm{~mm} \mathrm{H}, 0.18 \mathrm{~mm} \mathrm{~W}$ ).

Remarks.-The diagnosis of this species follows Jones (1862) and Anderson (1964). The original proposal of the species, however, is from Duff (1842), although it was not formally described or illustrated in that monograph. Its generic placement was changed to Suchonellina, as proposed by Spizharsky (1937) to accommodate Permo-Triassic darwinulocopine species from Russia. According to Rossetti and Martens (1998), the genus Darwinula presents different valve overlap and general 


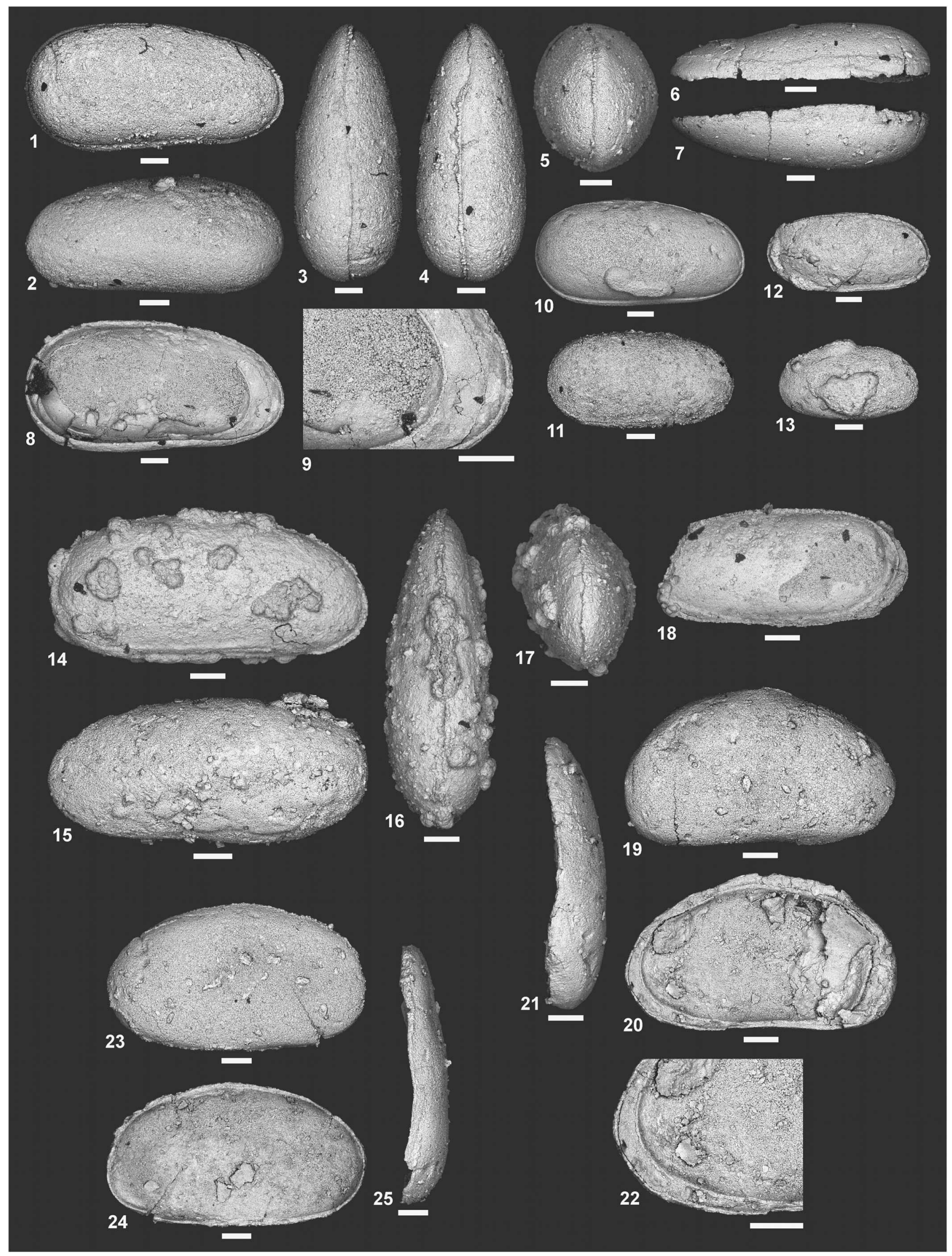


carapace size ratios in comparison to $S$. globosa. Other than that, some morphological characters attributed to Suchonellina by Molostovskaya (1990) seem to be observable in specimens of the present work: (1) in dorsal view, it is hinted that their hinge displays an arrangement of two marginal, enlarged protuberances separated by a sulcus in the right valve, and (2) the frontal view indicates a shifting upward of the right valve along the overlapping in the ventral margin. Darwinula maanshanensis Hou in Hou et al. (2002) (nom. nov. for the homonym $D$. longovata Wei in Wei, Li, and Jiang, 1983) also displays the aforementioned morphological characters and is herein synonymized with $S$. globosa. Specimens of 'S. globosa' were misfigured by Dadlez and Kopik (1963) as Notocythere media excelsa Will, 1953, and vice versa. Specimens identified as A-2 juveniles of D. sarytirmenensis Sharapova in Mandelstam, 1947 (misspelled as 'Darwinula sarytirmensis') by Kieztke and Lucas (1995) are actually adult individuals of S. globosa, based on the presence of a posterior brood pouch, clearly apparent in dorsal view. Synonymy with the present species is tentative for: (1) Darwinula (102) of Christensen (1962), because it is a similar, but slightly smaller, species; and (2) Darwinula spp. of Sohn and Chatterjee (1979) and (3) D. liulingchuanensis Zhong, 1964 of Wei et al. (1983), due to poor preservation of specimens affecting general layout observations. The size ratios between instars of $S$. globosa is like that found between ontogenetic stages of D. stevensoni and Vestalenula sp. by Smith and Kamiya (2008). However, Smith et al. (2006) noted that adult males of $V$. cornelia Smith, Kamiya, and Horne, 2006 are also similar in size ratios to A-1 juveniles. Therefore the present authors, while figuring some of the instars of S. globosa, attributed a doubtful identification to specimens identified as A-1 juveniles.

\section{Suchonellina stricta (Jones, 1894)}

Figure 5.14-5.19

1894 Darwinula globosa (Duff, 1842) var. stricta Jones, p. 164 , pl. 9 , fig. 5 .

?1963 Darwinula liassica; Dadlez and Kopik, p. 138, pl. 1, fig. 8.

1964 Darwinula stricta Jones, 1894; Anderson, p. 136, pl. 15, figs. 129-132.

1977 Darwinula cf. liassica (Brodie, 1843); Ye et al., p. 263, pl. 21, fig. 3a, b.

1983 Darwinula xinpingensis Jiang; Wei et al., p. 176, pl. 54, fig. 6D, R.

?1989a Gerdalia sp.; Kietzke, p. 186, fig. 4F.

1991 Gerdalia sp.; Kietzke and Lucas, p. 193, fig. 3A.

1999 Gerdalia sp.; Swain, p. 168, pl. 17, figs. 43, 44.

2002 Darwinula xinpingensis; Hou et al., p. 773, pl. 310, figs. 7,8 .
Lectotype.-BMNH I 6089, designated by Anderson (1964).

Occurrence.-Rhaetian, Upper Triassic, Penarth Group, Pylle hill, Bristol, Bristol County, England, UK (type locality); also at Glamorgan, Gloucestershire, Shropshire, and Warwickshire counties (Jones, 1894; Anderson, 1964). Rhaetian, Upper Triassic, Inner Moray Firth Basin, Linksfield, Elgin, Morayshire, Scotland, UK (Jones, 1894). Upper Triassic, Baijizu Formation, Yunnan, China (Ye et al., 1977). Uppermost Triassic, Shezi Formation, Yunnan, China (Wei et al., 1983). Carnian, Upper Triassic, Tecovas Formation, Texas, USA (Kieztke and Lucas, 1991). In the present work, extended to the Hettangian, Lower Jurassic, Whitmore Point Member, Moenave Formation, Arizona and Utah, USA.

Materials.-Carapaces: UMNH.IP 5299 (adult; $0.91 \mathrm{~mm} \mathrm{~L}$, $0.41 \mathrm{~mm} \mathrm{H}, 0.30 \mathrm{~mm} \mathrm{~W}$ ), UMNH.IP 5300 (adult; $0.84 \mathrm{~mm} \mathrm{~L}$, $0.38 \mathrm{~mm} \mathrm{H}, 0.31 \mathrm{~mm} \mathrm{~W}$ ). Valves: UMNH.IP 5298 (incomplete A-2 juvenile?, left; $0.34 \mathrm{~mm} \mathrm{H}, 0.13 \mathrm{~mm} \mathrm{~W}$ ).

Remarks.-For a discussion on the generic placement of this species in Suchonellina, see the Remarks section under S. globosa (above). The diagnosis of S. stricta follows Jones (1894) and Anderson (1964). The original proposal of the species, however, is from Brodie (1843), although the species was not formally described or illustrated in that monograph. Due to major morphological similarity between the type specimens of S. stricta and Darwinula xinpingensis Jiang in Wei et al. (1983), these are herein synonymized, as also are specimens of $D$. cf. D. liassica of Ye et al. (1977). Synonymy with the present species is tentative for: (1) D. liassica of Dadlez and Kopik (1963), because no size measurements for the illustrated specimens were given; and (2) Gerdalia sp. of Kietzke (1989a), also figured by Swain (1999), for having a very similar, but not equal, general layout.

Superfamily Darwinuloidoidea Molostovskaya, 1979 Family Darwinuloididae Molostovskaya, 1979

Genus Whipplella Holland, 1934

Type species.—Whipplella cuneiformis Holland, 1934.

Whipplella? sp. 1

Figure 5.20-5.22

?2006 Cypridoidea indet.; Schudack, p. 428, fig. 2H.

Occurrence.-Hettangian, Lower Jurassic, Whitmore Point Member, Moenave Formation, Arizona and Utah, USA.

Figure 5. Ostracodes of the Whitmore Point Member, Moenave Formation, Hettangian, Lower Jurassic, Utah and Arizona, USA: (1-13) Suchonellina globosa (Jones, 1862): $(\mathbf{1}, \mathbf{3}, \mathbf{4}, \mathbf{5})$ adult carapace (UMNH.IP 5293): (1) right lateral view; (3) dorsal view; (4) ventral view; (5) frontal view; (2) adult carapace (UMNH. IP 5303), left lateral view; (6, 8, 9) adult left valve (UMNH.IP 5296): (6) dorsal view; (8) internal view; (9) detail of the anterior inner lamella; (7) adult right valve (UMNH.IP 5297), dorsal view; (10) A-1? juvenile carapace (UMNH.IP 5301), right lateral view; (11) A-2 juvenile carapace (UMNH.IP 5292), right lateral view; (12) A-3 juvenile carapace (UMNH.IP 5302), right lateral view; (13) A-4 juvenile carapace (UMNH.IP 5304), right lateral view; (14-18) Suchonellina stricta (Jones, 1894): (14, 16, 17) adult carapace (UMNH.IP 5299): (14) right lateral view; (16) dorsal view; (17) frontal view; (15) adult carapace (UMNH.IP 5300), left lateral view; (18) A-2? right valve (UMNH.IP 5298), internal view; (19-22) Whipplella? sp. 1 (UMNH.IP 5294), right valve: (19) lateral view; (20) internal view; (21) dorsal view; (22) detail of the anterior inner lamella; (23-25) Whipplella? sp. 2 (UMNH.IP 5295), right valve: (23) lateral view; (24) internal view; (25) dorsal view. Scale bar $=100 \mu \mathrm{m}$. 
Material.-UMNH.IP 5294, valve $(0.79 \mathrm{~mm} \mathrm{~L}, 0.42 \mathrm{~mm} \mathrm{H}$, $0.18 \mathrm{~mm} \mathrm{~W})$.

Remarks.-The generic diagnosis follows Holland (1934) and Kukhtinov (2004). The single specimen of Whipplella? sp. 1 is badly preserved, which allows only a tentative placement in the genus Whipplella, based on the general shape of the valves in lateral and dorsal view. Whipplella? sp. 1 and Cypridoidea indet. by Schudack (2006) could be the same species, but the specimens of the latter are badly preserved, and the attribution is at best doubtful.

\section{Whipplella? sp. 2}

Figure 5.23-5.25

Occurrence.-Hettangian, Lower Jurassic, Whitmore Point Member, Moenave Formation, Arizona and Utah, USA.

Material.-UMNH.IP 5295, valve $(0.90 \mathrm{~mm} \mathrm{~L}, 0.49 \mathrm{~mm} \mathrm{H}$, $0.16 \mathrm{~mm} \mathrm{~W})$.

Remarks.-The generic diagnosis follows Holland (1934) and Kukhtinov (2004). The single specimen of Whipplella? sp. 2 is badly preserved, which allows only a tentative placement in the genus Whipplella, based on the general shape of the valves in lateral and dorsal view.

\section{Results and discussion}

In the present taxonomic review, four ostracode species were identified from sediments of the Whitmore Point Member, deposited in and along the margins of a lacustrine environment, referred throughout the region as Lake Dixie, and associated/ interbedded mudflat environments during the earliest Jurassic. The composition and stratigraphic position of this ostracode fauna makes it an interesting case to understand the demise of darwinulocopines as the main nonmarine ostracodes, both in terms of abundance and diversity, during early to middle Mesozoic times.

Evolutionary history of late Paleozoic-early Mesozoic darwinulocopines. - Darwinulocopines are known in the fossil record since the late Paleozoic (Carbonel et al., 1988). The group flourished during the Carboniferous-Triassic, an interval from which the majority of darwinulocopine families, genera, and species has been so far described. During that time, the group presented greater morphologic variety (Wang, 1980; Kashevarova and Neustrueva, 1982; Sohn, 1987; Molostovskaya, 1990) than shown by darwinulocopine flocks in earlier strata. Nonmarine faunas of the Carboniferous-Triassic also contained forms likely more closely related to the Carbonitidae Sohn, 1985 and Geisinidae Sohn in Benson et al., 1961 of the suborder Metacopina Sylvester-Bradley in Benson et al., 1961 (Martens et al., 1998; Tibert et al., 2013). Cytherocopines were also present in these environments, especially during the Permian, represented by orders such as the Permianoidea Sharapova in Schneider, 1948 and the Cytheroidea Baird, 1850 (Kashevarova, 1990).

Late Permian darwinulocopines were highly diverse in terms of morphology and taxa, and three superfamilies are present in the fossil record (Darwinuloidea, Suchonelloidea Mishina, 1972, and Darwinuloidoidea), each with its distinctive evolutionary history. They inhabited large, shallow lakes in which the variety of habitats was favorable to high diversity (Neustrueva, 1990). This apparently coincided with the presence of sexuality in at least some groups in this lineage, and Permian darwinulocopines commonly exhibited sexual dimorphism (Sohn, 1988; Molostovskaya, 2000). On the other hand, all modern darwinulocopines, except possibly one species (Smith et al., 2006), are exclusively parthenogenetic, and have apparently been so since late in the Mesozoic (Schön et al., 2009).

The Permian-Triassic (P-Tr) extinction event greatly reduced darwinulocopine diversity in nonmarine environments in ways similar to those observed in marine ones (Jin et al., 2000; Liu et al., 2010; Forel, 2013). It is still poorly known how these nonmarine faunas rebounded from such event during the Triassic, as they would soon be hit by another major extinction event, the ETE, which was probably caused by a disruption in the global carbon cycle due to emplacement of the Central Atlantic Magmatic Province (CAMP) (Beerling and Berner, 2002). The Upper Triassic also possibly witnessed the origin of the cytherocopine family Limnocytheridae Klie, 1938, which would become widespread in the Upper Jurassic-lower Cretaceous (Zhong, 1964; Zheng, 1976; Fang and Xu, 1978). The diversity of these faunas was maintained during the Lower Jurassic (Wakefield, 1994; Ballent and Díaz, 2012), only to be halved by the remainder of the period, before the explosive radiation of nonmarine cypridocopines, notably of the family Cyprideidae Bosquet, 1852, and the limnocytherids in the Middle-Late Jurassic (Whatley, 1988; Sames and Horne, 2012).

Proposed scenarios for the widespread dispersal of nonmarine darwinulocopines in the late Paleozoic range from transportation by early tetrapods, either in wet mud adhering to their feet or in the intestines of aquatic plant-feeding animals, to humid winds in warm, subtropical environments, considering that monsoons and hurricanes can carry wet particles for long distances (Lethiers and Damotte, 1993; Horne, 2003). Evidence suggests that darwinulocopines were also tolerant of stressed environments such as shallow, warm, hypersaline lagoons and saline lakes (Gramann, 1971; McKenzie, 1981; Molostovskaya, 2000). Certain morphophysiological traits that enabled their rapid spread through these and other habitats were present in darwinulocopine nonmarine faunas since at least the Permian (retaining eggs and juveniles in brood pouches) (Molostovskaya, 1990; Neustrueva, 1990) or the Early Jurassic (asexual reproduction by parthenogenesis). The record of parthenogenesis in darwinulocopines is a particularly remarkable one; despite being common in nonmarine ostracodes from several ages, it has not been the sole mechanism of reproduction in any other group for so long in the fossil record (Butlin et al., 1998; Martens et al., 1998; Schön et al., 2009). Exactly how long, however, is still a topic of discussion, although it is currently estimated to have persisted since 208 Ma ago (Martens et al., 2003).

Lake Dixie as the 'Last Hurrah of the Reigning Darwinulocopines'.-The strata of the Whitmore Point Member were deposited in Lake Dixie, soon after the ETE and the establishment of CAMP. The ostracode fossil record of this unit is marked by several mass mortality events, as evidenced by strata 


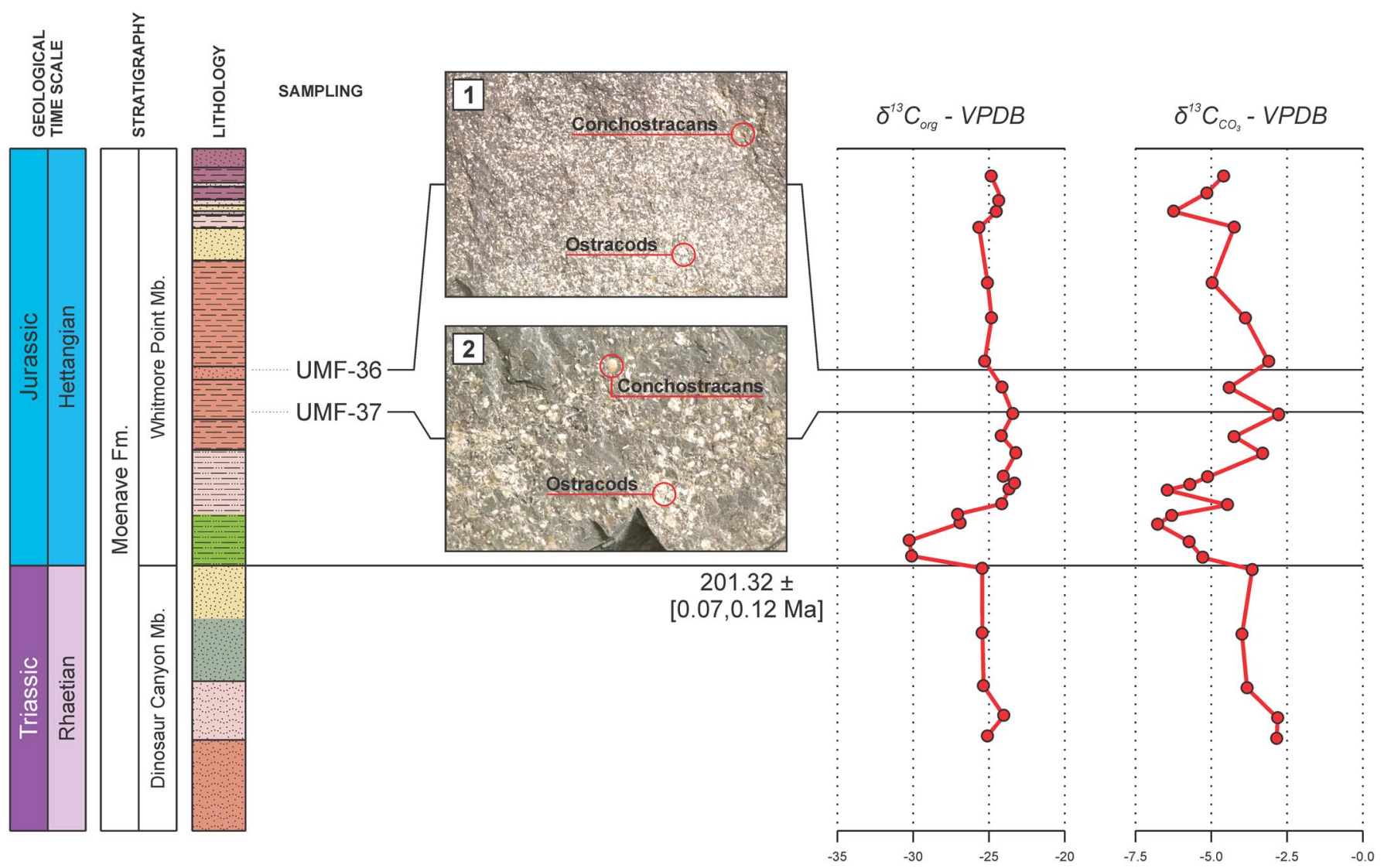

Figure 6. Ostracode extinction levels observed in the present work $(\mathbf{1}, \mathbf{2})$ in comparison with the inorganic and organic carbon isotope curves $\left(\delta^{13} \mathrm{C}\right)$ of the Potter Canyon section (Suarez et al., 2017), Mohave County, Arizona, USA. Note the up-and-down trend of the inorganic $\left(\mathrm{CO}_{3}\right) \mathrm{curve}(\mathrm{VPDB}=\mathrm{Vienna}$ Pee Dee Belemnite standard).

in the Olsen Canyon containing numerous, piled-up ostracode carapaces and valves that were deposited during what might be an up-and-down trend in local carbon isotope records (Suarez et al., 2017) (Fig. 6). These values are like those observed during the P-Tr extinction event, which was also associated with volcanic activity on a large igneous province in Siberia, Russia (Korte and Kozur, 2010).

Several horizons preserving mud cracks, triclinic sulfate crystal casts and algal mats indicate that Lake Dixie, although large, was relatively shallow, with sporadically fluctuating base levels (Kirkland and Milner, 2006; Kirkland et al., 2014). Sandstones with dinosaur tracks at the SGDS are interpreted as the shoreline area of the lake, and salt crystals were formed in the sediment of these shores during times of drought (Kirkland et al., 2002; Milner et al., 2006). Lake Dixie was bounded southeastward by coastal and fluvial deposits of the upper Dinosaur Canyon Member, and further east by the eolian, sanddune desert deposits known as the Wingate Sandstone (Blakey, 1994). Westward it was limited by the first stages of what would become the Nevadan orogeny by the end of the Jurassic (Renne and Turrin, 1987).

The diversity and composition of the Whitmore Point Member ostracode fauna agree with previous interpretations of the paleoenvironments of Lake Dixie. After the ETE, a very diversity-depleted fauna populated the member, comprising few species, one of which (Suchonellina globosa) was dominant in all of the currently analyzed samples containing sizable ostracode faunas. The majority of specimens recorded in the present work are females, and the very few that could be males are also interpretable as A-1 juveniles, according to the morphological parameters of Martens et al. (2003).

Similar faunas, both in terms of diversity and population composition, were also found in several formations that are coeval to the Moenave in Arizona, New Mexico, and Texas (Kietzke, 1987, 1989a, b; Kietzke and Lucas, 1991, 1995; Lucas and Kietzke, 1993). Lake Dixie was a shallow, occasionally saline lake, located at the center of a network of similar paleoenvironments in the southwestern USA. Along these regions, depauperated darwinulocopine faunas mostly had to overcome the effects of CAMP by deploying metabolic, but more probably reproductive (parthenogenesis), strategies that allowed them to occupy previously stressed environments after their recovery.

\section{Conclusions}

Four ostracode species of darwinulocopines were recovered from sediments of the Hettangian, Lower Jurassic, Whitmore Point Member of the Moenave Formation. These sediments were deposited in and along the margins of Lake Dixie and associated/interbedded mudflat environments in the counties of Washington and Mohave, Utah and Arizona, USA. The diversity and composition of the Whitmore Point Member ostracode fauna agree with previous interpretations of Lake Dixie as a 
paleoenvironment where depauperated darwinulocopine faunas survived by deploying parthenogenesis as a strategy to recolonize stressed environments soon after their recovery from the establishment of CAMP and subsequent ETE.

The darwinulocopine ostracodes had their origin in the late Paleozoic, but were significantly decimated by the P-Tr extinction event and the ETE, never having re-established similar diversities since these extinctions. Lake Dixie has one of the earliest records so far known of an exclusively darwinulocopine fauna, and could represent the last episode of darwinulocopine dominance in nonmarine environments before the Late Jurassic - Early Cretaceous diversification of the modern cypridocopine/cytherocopine ostracodefaunas. It is possible that the geographic isolation of Lake Dixie, and perhaps other nearby lakes, behind the Wingate Erg desert and the early stages of the Nevadan orogeny played a major role in isolating these environments from the explosive radiation of the cypridocopines and cytherocopines that ended the 'Last Hurrah of the Reigning Darwinulocopines.'

\section{Acknowledgments}

The authors wish to first acknowledge the late N.E. Tibert (1996-2015) for his efforts on the research of ostracode samples throughout the terrestrial Mesozoic sequences of Utah, which served as an important basis for the present work. We thank A. Smith (Department of Anthropology, UConn) for use of the SEM in taking the photographs for the present work. Also many thanks go to M. Suarez (Department of Geological Sciences, University of Texas at San Antonio) for support of field trips to Potter and Olsen canyons. LSA acknowledges J. Krishna for assistance with the cataloging of specimens deposited at NHMU. CAS wishes to thank G. McDonald and R. Hunt-Foster (Bureau of Land Management, Washington, D.C., USA) for support in obtaining field permit \#UT16-017S, which allowed for collection of samples in the Olsen Canyon area.

\section{Accessibility of supplemental data}

Data available from the Dryad Digital Repository: https://doi. org/10.5061/dryad.sh45f.

\section{References}

Anderson, F.W., 1964, Rhaetic Ostracoda: Bulletin of the Geological Survey of Great Britain, v. 21, p. 133-174.

Antonietto, L.S., Do Carmo, D.A., Viviers, M.C., and Adôrno, R.R., 2015 , Biostratigraphic and paleozoogeographic review of the upper AptianAlbian ostracods of Riachuelo Formation, Sergipe-Alagoas Basin, northeastern Brazil: Revista Brasileria de Paleontologia, v. 18, p. 355-368. doi: 10.4072/rbp.2015.3.02.

Antonietto, L.S., Do Carmo, D.A., Viviers, M.C., Queiroz Neto, J.V., and Hunt, G., 2016, Ostracoda (Arthropoda, Crustacea) from the Riachuelo Formation, Sergipe-Alagoas Basin, Brazil, upper Aptian-Albian: European Journal of Taxonomy, v. 244, 57 p. doi: 10.5852/ejt.2016.244.

Baird, W., 1850, The Natural History of the British Entomostraca: London, The Ray Society, $364 \mathrm{p}$.

Ballent, S.C., and Díaz, A.R., 2012, Contribution to the taxonomy, distribution and paleoecology, of the early representatives of Penthesilenula Rossetti \& Martens, 1998 (Crustacea, Ostracoda, Darwinulidae) from Argentina, with the description of a new species: Hydrobiologia, v. 688, p. 125-138. doi: 10.1007/s10750-011-0658-8.
Beerling, D.J., and Berner, R.A., 2002, Biogeochemical constraints on the Triassic-Jurassic boundary carbon cycle event: Global Biogeochemical Cycles, v. 16, p. 10-1-10-13. doi: 10.1029/2001GB001637.

Belousova, Z.D., 1961, [The ostracods of the Lower Trias]: Byulleten Moskovskogo Obshchestva Ispytateley Prirody: Otdel Geologicheskiy, v. 36, p. 127-147.

Benson, R.H., Berdan, J.M., Bold, W.A., Hanai, T., Hessland, I., Howe, H.V., Kesling, R.V., Levinson, S.A., Reyment, R.A., Moore, R.C., Scott, H.W., Shaver, R.H., Sohn, I.G., Stover, L.E., Swain, F.M., and Sylvester-Bradley, P.C., 1961, Systematic descriptions, in Moore R.C., and Pitrat, C.W., eds., Treatise on Invertebrate Paleontology, Part Q, Arthropoda 3: Boulder, Colorado, and Lawrence, Kansas, Geological Society of America (and University of Kansas Press), p. Q99-Q414.

Biek, R.F., Rowley, P.D., Hayden, J.M., Hacker, D.B., Willis, G.C., Hintze, L.F., Anderson, R.E., and Brown, K.D., 2009, Geologic map of the St. George and east part of the Clover mountains $30^{\prime}$ x $60^{\prime}$ quadrangles, Washington and Iron counties, Utah: Salt Lake City, Utah Geological Survey, $101 \mathrm{p}$

Biek, R.F., Willis, G.C., Hylland, M.D., and Doelling, H.H., 2010, Geology of Zion National Park, Utah, in Sprinkel, D.A., Chidsey, Jr., T.C., and Anderson, P.B., eds., Geology of Utah's Parks and Monuments: Utah Geological Association Publication, v. 28, p. 107-141.

Blakey, R., and Ranney, W., 2008, Ancient Landscapes of the Colorado Plateau: Grand Canyon, Arizona, The Grand Canyon Association, $156 \mathrm{p}$.

Blakey, R.C., 1994, Paleogeographic and tectonic controls on some Lower and Middle Jurassic erg deposits, Colorado Plateau, in Caputo, M.V., Peterson, J.A., and Franczyk, K.J., eds., Mesozoic Systems of the Rocky Mountain Region, USA: Denver, Colorado, SEPM (Society for Sedimentary Geology), Rocky Mountain Section, p. 273-298.

Bosquet, J., 1852, Description des Entomostracés Fossiles des Terrains Tertiaires de la France et de la Belgique: Brussels, M. Hayez, 133 p.

Brady, G.S., and Norman, A.M., 1889, A monograph of the marine and freshwater Ostracoda of the North Atlantic and of northwestern Europe, Section 1, Podocopa: Scientific Transactions of the Royal Dublin Society, v. $4, \mathrm{p}$ 63-270.

Brady, G.S., and Robertson, D., 1870, The Ostracoda and Foraminifera of tidal rivers, with an analysis and descriptions of the British Ostracoda: The Annals and Magazine of Natural History, v. 4, p. 1-33.

Branson, C.C., 1936, New name for a Morrison ostracode genus: Journal of Paleontology, v. 10, p. 323.

Brodie, P.B., 1843, A History of the Fossil Insects in the Secondary Rocks of England: London, John Van Voorst, $130 \mathrm{p}$.

Butlin, R., Schön, I., and Martens, K., 1998, Asexual reproduction in nonmarine ostracods: Heredity, v. 81 , p. 473-480.

Carbonel, P., Colin, J.P., Danielopol, D.L., Löffler, H., and Neustrueva, I., 1988 , Paleoecology of limnic ostracodes: A review of some major topics: Palaeogeography, Palaeoclimatology, Palaeoecology, v. 62, p. 413-461.

Chapman, F., 1901, On some fossils of Wenlock age from Mulde, near Klinteberg, Gotland: The Annals and Magazine of Natural History, v. 7, p. 141-160.

Christensen, O.B., 1962, Ostracodtyper fra Keuper=Rhaet lagserien i dybdeboringerne ved Harte og Ullerslev: Meddelelser fra Dansk Geologisk Forening, v. 15, p. 90-98.

Dadlez, R., and Kopik, J., 1963, Problem Retyku w zachodniej Polsce na tle profilu w Książu Wielkopolskim: Kwartalnik Geologiczny, v. 7, p. 131-159.

Donohoo-Hurley, L.L., Geissman, J.W., and Lucas, S.G., 2010, Magnetostratigraphy of the uppermost Triassic and lowermost Jurassic Moenave Formation, western USA: Correlation with strata in the United Kingdom, Morocco, Turkey, Italy, and eastern USA: GSA Bulletin, v. 122, p. 2005-2019. doi: 10.1130/B30136.1.

Duff, P., 1842, Sketch of the Geology of Moray: Elgin, Scotland, Forsyth \& Young, $72 \mathrm{p}$

Fang, J., and Xu, M., 1978, [Upper Triassic ostracods of Hunan, Jiangxi and northern Guangdong]: Acta Palaeontologica Sinica, v. 17, p. 131-148.

Federal Geographic Data Committee 2006, FGDC Digital Cartographic Standard for Geologic Map Symbolization: Federal Geographic Data Committee Document FGDC-STD-013-2006, 290 p.

Forel, M.B., 2013, The Permian-Triassic mass extinction: Ostracods (Crustacea) and microbialites: Comptes Rendus Geoscience, v. 345, p. 203-211. doi: 10.1016/j.crte.2013.03.003.

Gramann, F., 1971, Brackish or hyperhaline? Notes on paleoecology based on Ostracoda, in Oertli, H.J., ed., Colloque sur la Paléoécologie des Ostracodes: Pau, France, , 20-27 July 1970 Bulletin du Centre de Recherches Pau-SNPA, v. 5, p. 93-99.

Gründel, J., 1967, Zur Großgliederung der Ordnung Podocopida G. W. Müller, 1894 (Ostracoda): Neues Jahrbuch für Geologie und Paläontologie. Monatshefte, v. 1967 , no. 6, p. 321-332.

Harris, J.D., and Milner, A.R.C., 2015, Tracks in Deep Time: The St. George Dinosaur Discovery Site at Johnson Farm: Salt Lake City, University of Utah Press, 99 p. 
Hitchcock, E., 1845, An attempt to name, classify, and describe the animals that made the fossil footmarks of New England: Abstract of the Proceedings of the Sixth Annual Meeting of the Association of American Geologists and Naturalists, New Haven, Connecticut, April 1845, p. 23-25.

Hitchcock, E., 1848, An attempt to discriminate and describe the animals that made the fossil footmarks of the United States, and especially of New England: Memoirs of the American Academy of Arts and Sciences, n. s., v. 3, p. $129-256$.

Holland, W.C., 1934, The ostracods of the Nineveh limestone of Pennsylvania and West Virginia: Annals of Carnegie Museum, v. 22, p. 343-350.

Horne, D.J., 2003, Key events in the ecological radiation of the Ostracoda, in Park, L.E., and Smith, A.J., eds., Bridging the Gap: Trends in the Ostracode Biological and Geological Sciences: The Paleontological Society Papers, p. 181-201.

Hou, G., Gou, Y., and Chen, D., 2002, Zhōngguó Jiè Xíng Lèi Huàshí. Dì Yī Juàn. Cypridacea hé Darwinulidacea: Beijing, Science Press, 1090 p.

Jin, Y.G., Wang, Y., Wang, W., Shang, Q.H., Cao, C.Q., and Erwin, D.H., 2000, Pattern of marine mass extinction near the Permian-Triassic boundary in South China: Science, v. 289, p. 432-436.

Jones, T.R., 1862, A Monograph of the Fossil Estheriæ: London, J.E. Adlard, 134 p.

Jones, T.R., 1894, On the Rhætic and some Liassic Ostracoda of Britain: Quarterly Journal of the Geological Society, v. 50, p. 156-168.

Jones, T.R., 1885, On the Ostracoda of the Purbeck Formation, with notes on the Wealden species: Quarterly Journal of the Geological Society, v. 41, p. 311-353.

Kashevarova, N.P., 1990, [Suborder Cytherocopina], in Sokolov, B.S., ed., Prakticheskoye Rukovodstvo po Mikrofaune SSSR, Volume 4, Ostrakodi Paleozoya: Leningrad Nedra, p. 167-171 [in Russian with English summary].

Kashevarova, N.P., and Neustrueva, I.Y., 1982, [The present state of the problem and classification principles of ostracod superfamily Darwinulacea, Brady et Norman, 1889], in Rauser-Chernousova, D.M., ed., Systematics and Morphology of Microfossils: Questions of Micropaleontology, v. 25, p. 141-154.

Kietzke, K., and Lucas, S.G., 1991, Ostracoda from the Upper Triassic (Carnian) Tecovas Formation near Kalgary, Crosby County, Texas: The Texas Journal of Science, v. 43, p. 191-197.

Kietzke, K.K., 1987, Calcareous microfossils from the Upper Triassic of northeastern New Mexico, in Lucas, S.G., and Hunt, A.P., eds., Northeastern New Mexico: New Mexico Geological Society Fall Field Conference Guidebook 38: Socorro, New Mexico Geological Society, p. 119-126.

Kietzke, K.K., 1989a, Calcareous microfossils from the Moenkopi Formation (Triassic, Scythian or Anisian) of central New Mexico, in Anderson, O.J., Lucas, S.G., Love, D.W., and Cather, S.M., eds., Southeastern Colorado Plateau: New Mexico Geological Society Fall Field Conference Guidebook 40: Socorro, New Mexico Geological Society, p. 181-190.

Kietzke, K.K., 1989b, Calcareous microfossils from the Triassic of the southwestern USA, in Lucas, S.G., and Hunt, A.P.. , Dawn of the Age of Dinosaurs in the American Southwest: Albuquerque, New Mexico Museum of Natural History, p. 223-232.

Kietzke, K.K., and Lucas, S.G., 1995, Ostracoda and Gastropoda from the Kayenta Formation (Lower Jurassic) of Arizona, U.S.A.: Journal of the Arizona-Nevada Academy of Science, v. 28, p. 23-32.

King, W., 1850, A Monograph of the Permian Fossils of England: London, C. and J. Adlard, $258 \mathrm{p}$.

Kirkland, J.I., and Milner, A.R.C., 2006, The Moenave Formation at the St. George Dinosaur Discovery Site at Johnson Farm, St. George, southwestern Utah, in Harris, J.D., Lucas, S.G., Spielmann, J.A., Lockley, M.G., Milner, A.R. C., and Kirkland, J.I., eds., The Triassic-Jurassic Terrestrial Transition: New Mexico Museum of Natural History and Science Bulletin 37, p. 289-298.

Kirkland, J.I., Lockley, M., and Milner, A.R., 2002, The St. George Dinosaur Tracksite: Utah Geological Survey Notes, v. 34, p. 4, 5, 12.

Kirkland, J.I., Milner, A.R.C., Olsen, P.E., and Hargrave, J.E., 2014, The Whitmore Point Member of the Moenave Formation in its type area in northern Arizona and its age and correlation with the section in St. George, Utah: Evidence for two major lacustrine sequences, in MacLean, J.S., Biek, R.F., and Huntoon, J.E., eds., Geology of Utah's Far South: Utah Geological Association Publication 43, p. 321-356.

Klie, W., 1938, Ostracoda, Muschelkrebse. Die Tierwelt Deutschlands und der Angrenzenden Meeresteile nach Ihren Merkmalen und nach Ihrer Lebensweise: Jena, Verlag von Gustav Fischer, 230 p.

Korte, C., and Kozur, H.W., 2010, Carbon-isotope stratigraphy across the Permian-Triassic boundary: A review: Journal of Asian Earth Sciences, v. 39 , p. $215-235$.

Kozur, H., 1972, Einige Bemerkungen zur Systematik der Ostracoden und Beschreibung neuer Platycopida aus der Trias Ungarns und der Slowakei: Geologisch-Paläontologische Mitteilungen Innsbruck, v. 2, no. 10, p. 1-27.

Kukhtinov, D.A., 1985, Sistema ostrakod nadsemeystva Darwinulaceae: Paleontological Journal, v. 1985, p. 64-69.
Kukhtinov, D.A., 2004, The genus Darwinuloides Mandelstam, 1956 (Ostracoda), a junior synonym of the genus Whipplella Holland, 1934: Paleontological Journal, v. 38, p. 393-395.

Latreille, P.A., 1802, Histoire Naturelle, Generale et Particulière, des Crustacés et des Insectes, Principes Élémentaires, Volume 1: Paris, F. Dufart, 382 p.

Lethiers, F., and Damotte, R., 1993, La grande dispersion des espèces d'ostracodes (Crustacea) d'eau douce à la fin de l'ère primaire: Comptes Rendues de l'Academie des Sciences, Paris, v. 316, p. 427-433.

Liebau, A., 2005, A revised classification of the higher taxa of the Ostracoda (Crustacea): Hydrobiologia, v. 538, p. 115-137. doi: 10.1007/s10750-0044943-7.

Liu, H., Wang, Y.B., Yuan, A.H., Yang, H., Song, H.J., and Zhang, S.X., 2010, Ostracod fauna across the Permian-Triassic boundary at Chongyang, Hubei Province, and its implication for the process of the mass extinction: Science China - Earth Sciences, v. 53, p. 810-817.

Lucas, S.G., and Kietzke, K.K., 1993, Calcareous microfossils from the Upper Triassic of Petrified Forest National Park, Arizona: Journal of the ArizonaNevada Academy of Science, v. 27, p. 55-68.

Lucas, S.G., and Tanner, L.H., 2006, The Springdale Sandstone of the Kayenta Formation, Lower Jurassic of Utah-Arizona, in Harris, J.D., Lucas, S.G., Spielmann, J.A., Lockley, M.G., Milner, A.R.C., and Kirkland, J.I., eds., The Triassic-Jurassic Terrestrial Transition: New Mexico Museum of Natural History and Science Bulletin 37, p. 71-76.

Lucas, S.G., and Tanner, L.H., 2007, Tetrapod biostratigraphy and biochronology of the Triassic-Jurassic transition on the southern Colorado Plateau, USA: Palaeogeography, Palaeoclimatology, Palaeoecology, v. 244, p. 242-256. doi: 10.1016/j.palaeo.2006.06.030.

Lucas, S.G., Heckert, A.B., Estep, J.W., and Anderson, O.J., 1997, Stratigraphy of the Upper Triassic Chinle Group, Four Corners region, in Anderson, O.J., Kues, B.S., and Lucas, S.G., eds., Mesozoic Geology and Paleontology of the Four Corners Region: New Mexico Geological Society Fall Field Conference Guidebook 48: Socorro, New Mexico Geological Society, p. 81-108.

Lucas, S.G., Tanner, L.H., Donohoo-Hurley, L.L., Geissman, J.W., Kozur, H. W., Heckert, A.B., and Weems, R.E., 2011, Position of the Triassic-Jurassic boundary and timing of the end-Triassic extinctions on land: Data from the Moenave Formation on the southern Colorado Plateau, USA: Palaeogeography, Palaeoclimatology, Palaeoecology, v. 302, p. 194-205. doi: 10.1016/j.palaeo.2011.01.009.

Mandelstam, N.I., 1947, Ostracoda iz otlozheniy Sredney Yury poluostrova Mangyshlaka, in Subbotina, N.N., ed., Mikrofauna Neftyanykh Mestorozhdeniy Kavkaza, Emby i Sredney Azii: Trudy VNIGRI 57, p. 239-259.

Mandelstam, M.I., 1956, Ostrakodi uglenosnykh otlozheniy Kuznetskogo Basseyna, in Andreeva, E.M., Mandelstam, M.O., Radchenko, G.P., Rota, A.P., Khalfina, L.L., and Yavorsky, V.I., eds., Atlas Rukovodyashchikh Form Iskopayemykh Fauny i Flory Permskikh Otlozheniy Kuzneukogo Basseyna: Moscow, Gosudarstvennoye Nauchno-Tekhnicheskoye Izdatel'stvo Literatury po Ekologii i Okhrane Nedr, p. 58-109.

Martens, K., Horne, D.J., and Griffiths, H.I., 1998, Age and diversity of nonmarine ostracods, in Martens, K., ed., Sex and Parthenogenesis: Evolutionary Ecology of Reproductive Modes in Non-Marine Ostracods: Leiden, The Netherlands, Backhuys Publishers, p. 37-55.

Martens, K., Rossetti, G., and Horne, D.J., 2003, How ancient are ancient asexuals?: Proceedings of the Royal Society, ser. B, v. 270, p. 723-729. doi: 10.1098/rspb.2002.2270

Martz, J.W., Kirkland, J.I., Milner, A.R.C., Parker, W.G., and Santucci, V.L., 2017, Upper Triassic lithostratigraphy, depositional systems, and vertebrate paleontology across southern Utah: Geology of the Intermountain West, v. 4, p. $99-180$.

Mathis, A.C., 2000, Capitol Reef National Park and Vicinity geologic road logs, Utah, in Anderson, P.B., and Sprinkel, D.A., eds., Geologic Road, Trail, and Lake Guides to Utah's Parks and Monuments: Utah Geological Association Publication 29, $76 \mathrm{p}$.

McKenzie, K.G., 1981, Palaebiogeography of some salt lake faunas: Hydrobiologia, v. 82, p. 407-418.

Milner, A.R.C., and Kirkland, J.I., 2006, Preliminary review of an Early Jurassic (Hettangian) freshwater Lake Dixie fish fauna in the Whitmore Point Member, Moenave Formation in southwest Utah: New Mexico Museum of Natural History and Science Bulletin 37, p. 510-521.

Milner, A.R.C., Lockley, M.G., and Johnson, S.B., 2006, The story of the St. George dinosaur discovery site at Johnson farm: An important new Lower Jurassic dinosaur tracksite from the Moenave Formation of southwestern Utah, in Harris, J.D., Lucas, S.G., Spielmann, J.A., Lockley, M.G., Milner, A.R.C., and Kirkland, J.I., eds., The Triassic-Jurassic Terrestrial Transition: New Mexico Museum of Natural History and Science Bulletin 37, p. 329-345.

Milner, A.R.C., Birthisel, T.A., Kirkland, J.I., Breithaupt, B.H., Matthews, N.A., Lockley, M.G., Santucci, V.L., Gibson, S.Z., DeBlieux, D.D., Hurlbut, M., Harris, J.D., and Olsen, P.E., 2012, Tracking Early Jurassic dinosaurs across southwestern Utah and the Triassic-Jurassic transition, in Bonde, J.W., and Milner, A.R.C., eds., Field Trip Guide Book, 71st Annual Meeting of the 
Society of Vertebrate Paleontology, Paris Las Vegas, Las Vegas, Nevada, November 2-5, 2011: Nevada State Museum Paleontological Papers 1, $107 \mathrm{p}$ Mishina, E.M., 1972, [On the question of systematic of fossil Darwinulidae (Ostracoda)]: Paleontologicheskiy Sbornik, v. 9, p. 44-51.

Molostovskaya, I.I., 1979, O sistematike i printsipakh klassifikatsii pozdnepermskikh Darwinulacea, in Negadaev, K.N., ed., Evolyutsiya, Sistematika, Ekologiya Ostrakod i Voprosy Biostratigrafii, Materialy, IV, Vsesoyuznogo Simpoziuma po Ostrakodam: Chişinău, Moldova, Otdel Paleontologii i Stratigrafii Akademii Nauk Moldavskoy SSR, p. 51-54.

Molostovskaya, I.I., 1980, Utochneniye sistematicheskogo sostava Pozdnepermsnikh ostrakod Nadsemeystva Darwinulacea, in Morosov, N.S., ed., Voprosy Geologii Yuzhnogo Urala i Povolzhya: Mezhvuzovskiy Nauchnyy Sbornik 19, p. 25-34.

Molostovskaya, I.I., 1982, [Certain principles of systematics of Late Permian Darwinulacea], in Rauser-Chernousova, D.M., ed., Systematics and Morphology of Microfossils: Questions of Micropaleontology, p. 155-163.

Molostovskaya, I.I., 1990, [Suborder Darwinulocopina Sohn, 1988], in Sokolov, B.S., ed., Prakticheskoye Rukovodstvo po Mikrofaune SSSR, Volume 4, Ostrakodi Paleozoya: Leningrad Nedra, p. 162-166.

Molostovskaya, I.I., 1996, Ostrakodi verkhney Permi Volgo-Vyatskogo Basseyna, in Esaulova, N.K., and Lozovsky, V.R., eds., Stratotypes and Reference Sections of the Upper Permian of Regions of the Volga and Kama Rivers: Kazan, Russia, Ekotsentr, p. 227-242.

Molostovskaya, I.I., 2000, The evolutionary history of Late Permian Darwinulocopina Sohn, 1988 (Ostracoda) from the Russian Plate: Hydrobiologia, v. 419 , p. $125-130$.

Moore, R.C., 1961, Glossary of morphological terms applied to Ostracoda, in Moore R.C., and Pitrat, C.W., eds., Treatise on Invertebrate Paleontology, Part Q, Arthropoda 3: Boulder, Colorado, and Lawrence, Kansas, Geological Society of America (and University of Kansas Press), p. Q47-Q56.

Neustrueva, I.J., 1990, [Ostracods of Paleozoic continental basins], in Sokolov, B.S., ed., Prakticheskoye Rukovodstvo po Mikrofaune SSSR, Volume 4 Ostrakodi Paleozoya: Leningrad Nedra, p. 191-196.

Olsen, P.E., Kent, D.V., Sues, H.D., Koeberl, C., Huber, H., Montanari, A., Rainforth, E.C., Fowell, S.J., Szajna, M.J., and Hartline, B.W., 2002, Ascent of dinosaurs linked to an iridium anomaly at the Triassic-Jurassic boundary: Science, v. 296, p. 1305-1307. doi: 10.1126/science.1065522.

Renne, P.R., and Turrin, B.D., 1987, Constraints on timing of deformation in the Benton Range, southeastern California, and implications to Nevadan orogenesis: Geology, v. 15, p. 1031-1034.

Rossetti, G., and Martens, K., 1998, Taxonomic revision of the Recent and Holocene representatives of the family Darwinulidae (Crustacea, Ostracoda), with a description of three new genera: Bulletin de l'Institut Royal des Sciences Naturelles de Belgique, Biologie, v. 68, p. 55-110.

Sames, B., and Horne, D.J., 2012, Latest Jurassic to Cretaceous non-marine ostracod biostratigraphy: Unde venis, quo vadis?: Journal of Stratigraphy, $v$. 36, p. 266-288.

Sars, G.O., 1866, Oversigt af Norges marine ostracoder: Forhandlinger i Videnskabsselskabet, v. 7, $130 \mathrm{p}$.

Schneider, G.F., 1948, Fauna Verkhnepermskikh otlozheniy (Tatarskiy i Kazanskiy yarusy) neftenosnykh rayonov SSSR: Trudy VNIGRI, Novaya Seriya, v. 31, p. 21-48.

Schön, I., Rossetti, G., and Martens, K., 2009, Darwinulid ostracods: Ancient asexual scandals or scandalous gossip?, in Schön, I., Martens, K., and Dijk, P., eds., Lost Sex: The Evolutionary Biology of Parthenogenesis: Dordrecht, Springer Netherlands, p. 217-240.

Schudack, M.E., 2006, Basal Jurassic nonmarine ostracods from the Moenave Formation of St. George, Utah, in Harris, J.D., Lucas, S.G., Spielmann, J.A., Lockley, M.G., Milner, A.R.C., and Kirkland, J.I., eds., The TriassicJurassic Terrestrial Transition: New Mexico Museum of Natural History and Science Bulletin 37, p. 427-431.

Schudack, M.E., Turner, C.E., and Peterson, F., 1998, Biostratigraphy, paleoecology and biogeography of charophytes and ostracodes from the Upper Jurassic Morrison Formation, Western Interior, USA: Modern Geology, v. 22, p. 379-414.

Smith, R.J., and Kamiya, T., 2008, The ontogeny of two species of Darwinuloidea (Ostracoda, Crustacea): Zoologischer Anzeiger, v. 247, p. 275-302. doi: 10.1016/jcz.2008.05.002.

Smith, R.J., Kamiya, T., and Horne, D.J., 2006, Living males of the 'ancient asexual' Darwinulidae (Ostracoda: Crustacea): Proceedings of the Royal Society, ser. B, v. 273, p. 1569-1578. doi: 10.1098/rspb.2005.3452.

Sohn, I.G., 1985, Latest Mississippian (Namurian A) nonmarine ostracodes from West Virginia and Virginia: Journal of Paleontology, v. 59, p. 446-460.

Sohn, I.G., 1987, The ubiquitous ostracode Darwinula stevensoni (Brady and Robertson, 1870), redescription of the species and lectotype designation: Micropaleontology, v. 33, p. 150-163.
Sohn, I.G., 1988, Darwinulocopina (Crustacea: Podocopa), a new suborder proposed for nonmarine Paleozoic to Holocene Ostracoda: Proceedings of the Biological Society of Washington, v. 101, p. 817-824.

Sohn, I.G., and Chatterjee, S., 1979, Freshwater ostracodes from late Triassic coprolite in central India: Journal of Paleontology, v. 53, p. 578-586.

Spizharsky, T.N., 1937, [Ostracoda from the Kolchugino Series of the coal-bearing strata of the Kuznetsk Basin]: Trudy Vserossiiskii Neftianoi NauchnoIssledovatelskii Geologorazvedochnyi Institut (VNIGRI), v. 97, p. 139-171.

Su, D., Li, Y., Pang, Q., and Chen, S., 1980, Jiè xíng chóng huàshí, in Institute of Geology, Chinese Academy of Geological Sciences ed., Shăn Gān Níng Péndì Zhōngshēngdài Dìcéng Gǔshēngwù, Xià Cè: Beijing, Geological Publishing House, p. 48-83.

Suarez, C., Knobbe, T.K., Crowley, J.L., Kirkland, J.I., and Milner, A.R.C., 2017, A chronostratigraphic assessment of the Moenave Formation, USA using $\mathrm{C}$-isotope chemostratigraphy and detrital zircon geochronology: Implications for the terrestrial end Triassic extinction: Earth and Planetary Science Letters, v. 475, p. 83-93. doi: 10.1016/j.eps1.2017.07.028.

Swain, F.M., 1999, Fossil nonmarine Ostracoda of the USA: Developments in Palaeontology and Stratigraphy, v. 16, $401 \mathrm{p}$.

Tanner, L.H., and Lucas, S.G., 2007, The Moenave Formation: Sedimentologic and stratigraphic context of the Triassic-Jurassic boundary in the Four Corners area, southwestern U.S.A.: Palaeogeography, Palaeoclimatology, Palaeoecology, v. 244, p. 111-125. doi: 10.1016/j.palaeo.2005.06.039.

Tanner, L.H., and Lucas, S.G., 2009, The Whitmore Point Member of the Moenave Formation: Early Jurassic dryland lakes on the Colorado Plateau, southwestern USA: Volumina Jurassica, v. 6, p. 11-21.

Tibert, N.E., Rygel, M.C., Sanders, S.C., Elrick, S.D., and Nelson, J., 2013 , Temporal and spatial distribution of ostracodes across the PennsylvanianPermian boundary interval in eastern North America: International Journal of Coal Geology, v. 119, p. 93-105. doi: 10.1016/j.coal.2013.08.002.

Wakefield, M.I., 1994, Middle Jurassic (Bathonian) Ostracoda from the Inner Hebrides, Scotland: Monograph of the Palaeontographical Society, v. 148, 89 p.

Wakefield, M.I., 1996, Variation in the adductor muscle-scar rosette of Darwinula cicatricosa Wakefield, 1994 (Ostracoda, Crustacea), and comparison with other species of Darwinula: Journal of Micropalaeontology, v. 15 , p. $151-160$.

Wang, S., 1980, [Panxianiidae, a new family of non-marine Ostracoda]: Acta Palaeontologica Sinica, v. 19, p. 302-310.

Wei, M., 1984, Late Triassic and Jurassic ostracods from Sichuan. in Institute of Geology and Mineral Resources, Geological Bureau of Sichuan Province ed., Continental Mesozoic Stratigraphy and Paleontology in Sichuan Basin of China, Part II, Paleontological Profisional (sic) Papers: Chengdu, China, People's Publishing House of Sichuan, p. 346-364.

Wei, M., Li, Y., and Jiang, Z., 1983, Dáérwén jiè qiǐ kē superfamily Darwinulacea. in Chengdu Institute of Geology and Mineral Resources ed., Paleontological Atlas of Southwest China, Volume of Microfossils: Beijing, China, Geological Publishing House, p. 171-180.

Whatley, R.C., 1988, Patterns and rates of evolution among Mesozoic Ostracoda, in Hanai, T., lkeya, N., and Ishizaki, K., eds., Evolutionary Biology of Ostracoda-Its Fundamentals and Applications, Proceedings of the Ninth International Symposium on Ostracoda, Shizuoka, Japan, 29 July - 2 August 1985: Developments in Palaeontology and Stratigraphy 11, p. 1021-1040.

Wicher, C.A., 1951, Zur mikropaläontologischen Gliederung des nichtmarinen Rät: Erdöl und Kohle, v. 12, p. 755-760.

Will, H., 1953, Paläontologische Untersuchungen zur Stratigraphie des Oberkeuper in Nordwestdeutschland [Ph.D. thesis]: Tübingen, Eberhard Karls University, 248 p.

Wilson, R.F., 1967, Whitmore Point, a new member of the Moenave Formation in Utah and Arizona: Plateau, v. 40, p. 29-40.

Xu, M., 1988, Ostracods from the Mesozoic coal-bearing strata of northern Shaanxi, China, in Hanai, T., lkeya, N., and Ishizaki, K., eds., Evolutionary Biology of Ostracoda - Its Fundamentals and Applications, Proceedings of the Ninth International Symposium on Ostracoda, Shizuoka, Japan, 29 July -2 August 1985: Developments in Palaeontology and Stratigraphy 11, p. 1283-1291.

Ye, C., Gou, Y., Hou, Y., and Cao, M., 1977, Yúnnán Zhōng, Xīnshēng Dài jiè xíng lèi dòngwù qún. in Chinese Academy of Geological Sciences ed., Yúnnán Zhōngshēngdài Huàshí. Xià Cè: Beijing, China, Science Press, p. 153-330.

Zheng, S., 1976, [Early Mesozoic ostracods from some localities in southwest China]: Acta Palaeontologica Sinica, v. 15, p. 77-93.

Zhong, X., 1964, Upper Triassic and Middle Jurassic ostracods from the Ordos Basin: Acta Palaeontologica Sinica, v. 12, p. 426-465.

Accepted 4 December 2017 